\title{
CONCURRENT INFECTION OF GASTRO-INTESTINAL PARASITES AND BACTERIA ASSOCIATED WITH DIARRHOEA IN CALVES
}

\author{
M. A. Samad, K. M. M. Hossain', M. A. Islam and S. Saha ${ }^{1}$ \\ Department of Medicine, Departiment of Microbiology and Hygiene ${ }^{1}$, Faculty of Veterinary Science, Bangladesh \\ Agricultural University, Mymensingh - 2202, Bangladesh
}

\begin{abstract}
Bacterio-parasitological examination of faecal samples of randomly selected 100 diarrhoeic calves aged between 10 to 180 days, were carried out to determine the parasites and bacteria associated with 'iarrhea in calves. These calves ( either sexes and both local \& cross-bred ) were brought for treatment at the Bangladesh Agricultural University Veterinaty Clinic, Mymensingh during the two years period from June 1999 to May 2001. Of the 100 faecal samples examined, of which $67 \%$ calves affected with different parasites and $98 \%$ with different bacteria. Of the 67 and 98 calves affected with parasites and bacteria, of which $65.67 \%$ and $61.22 \%$ had single, $29.85 \%$ and $37.76 \%$ had dual and only $3.33 \%$ and $1.02 \%$ had triple concurrent infection, respectively. Analysis of the results of bacterio-parasitic enteropathogens of 100 calves revealed that highest percentage ( $66 \%$ ) calves were infected with concurrent parasitic and bacterial infection, followed by $18 \%$ with single bacteria, $14 \%$ with concurrent bacteria, and only $1 \%$ with concurrent parasitic infection but the faecal sample of one diarnhoeic calf showed negative for both bacteria and parasitic infections. Highest rate of gastro-intestinal nematodes ( GIN) infection ( $48 \%$ ) was recorded in calves, followed by Eimeria spp. ( $27 \%$ ), Toxocara vitulorum (14\%) and lowest ( $1 \%$ ) with each of the Strongyloides, Paramphistomum and Moniezia sp. The clinical T. vitulorum infection was first recorded at the age of 15 days, GIN at 30 days, Strongyloides at 45 days, Paramphistomum at 150 days and Eimeria infection at 25 days. Similarly, the rate of Bacillus infection ( $87 \%$ ) was found highest, followed by E. coli ( $37 \%$ ), Staphylococcus ( $9 \%$ ) and lowest of Salmonella ( $5 \%$ ) infection. Although the Bacillus and E. coli recorded first time at the 10 days and Staphylococcus at 30 days age of calves but Salmonella was recorded at the age of 60 days. A characteristic age specific prevalence of both parasite and bacterial enteropathogens was observed. It may be concluded from this study that concurrent infections with parasites or bacteria or both are mainly associated with diarrhea in calves.
\end{abstract}

Key words : Concurrent infection, GI parasites, bacteria, diarrhea, calves

\section{INTRODUCTION}

Diarrhoea, caused by different enteropathogens has been recognized as a major clinical problem for calves in Bangladesh ( Debnath et al., 1987 ). Debnath et al. (1990) reported 52\% calf morbidity and mortality caused by gastroenteritis in Bangladesh. Enteropathogens include bacteria, viruses, fungi, protozoa and helminths have been recognized to be associated with diarrhoea ( Radostits et al., 2000 ). Reports on enteropathogens associated with calf diarrhoea are very limited from Bangladesh ( Samad et al., 1977 ; Debnath et al., 1987; Amin et al., 1988 ). Therefore, an attempt was made to determine the parasites and bacteria associated with calf diarrhoea in Bangladesh.

\section{MATERIALS AND METHODS}

This study was carried out on randomly selected 100 clinically diarthoeic calves, aged between 10 to 180 days, of either sexes and both the local and cross-bred, which were brought for treatment at the BAU Veterinary Clinic, Mymensingh during two years period from June 1999 to May 2001. Faecal samples of each of the selected 100 diarthoeic calves were collected directly from the rectum aseptically in sterile vials and transferred to the laboratory for examination and occasionally stored at $-20^{\circ} \mathrm{C}$ until tested.

\section{Parasitological examination}

Most of the tapeworm and ascarid infection in calves was recognized with naked eye at the time of collection of faecal samples by the presence of segments and adult ascarid worms in the faeces, respectively. The tapeworm segments were grinded with mortar and pestle with small amount of water and then the fluid was examined under microscope to confirm the Moniezia sp. Each of the collected faecal sample was examined on conventional direct smear method and followed by sedimentation methods to detect the parasitic eggs which were identified by their morphological features as described by Samad (2001a). As it was difficult to differentiate the eggs of different species of nematode parasites and accordingly, they were grouped as GI nematode parasites. Faecal samples found positive for parasitic infection on direct conventional method were also examined by quantitative Stoll's dilution technique for counting egg per gram ( epg ) of faeces for helminths eggs and MacMaster method for counting Eimeria oocyst as described by Samad (2001a), and epg $\geq 200$ and oocyst $\geq 5000 / \mathrm{g}$ of faeces were considered significant for clinical infections ( Samad, 2000). 


\section{Bacteriological examination}

All the 100 randomly selected diarrhoeic faecal samples of calves were examined for isolation and identification of bacteria. Each of the faecal samples was streaked on Nutrient agar and Blood agar to promote growth of bacteria. The colonies on primarily cultures were repeatedly subcultured by streak plate method ( Cheesbrough, 1985 ) until pure culture with homogenous colonies were obtained. Media like Nutrient agar, Blood agar, Staphylococcus medium No. 110, Eosin Methylene blue ( EMB ), MacConkey agar, Triple sugar iron, Salmonella-Shigella agar ( SSA ) were used for subcultures. Bacteria were identified on cultural, morphological characters and biochemical ( sugar fermentation, catalase, coagulase \& IMViC utilization ) tests as described by Cowan ( 1985 ).

\section{Statistical analysis}

The results were analyzed statistically by using Chi-square test for significance ( Gupta, 1982 ).

\section{RESULTS AND DISCUSSION}

Bacterio-parasitological methods were used to determine the gastro-intestinal bacteria and parasites associated with diarrhoea in calves. The age of calves and pathogen factors ( single and concurrent infection ) were assessed for the occurrence of the disease. The faecal examination of 100 diarrhoeic calves revealed that $67 \%$ calves were affected with different types of GI parasites ( Table 1 ) and $98 \%$ calves had different types of bacterial infections ( Table 2 ). These observations support the earlier reports of Hossain et al. (1992) who reported $58.2 \%$ mortality of calves due to GI helminthiasis and Samad (2001b) reported $82.62 \%$ clinically sick calves had Gl parasitic infection. Of the $67 \%$ calves affected with GI parasites, of which $65.67 \%$ had single, $29.85 \%$ dual and only $3.33 \%$ three types of concurrent parasitic infection ( Table 1 ). This finding supports the earlier report of Samad (2001b) who reported $63.32 \%$ single, $33.74 \%$ dual and only $2.94 \%$ triple GI parasitic infection in calves. Similarly, of the 98 diarrhoeic calves affected with bacterial enteropathogens, of which $61.22 \%$ had single type, $37.76 \%$ had 2 types and only $1.02 \%$ had three types of infection ( Table 2 ). Analysis of the result showed that calves aged between 10 to 30 days had low level of both parasite ( $11.94 \%$ ) and bacterial ( $16.33 \%$ ) infections in comparison to 31 to 90 days $(37.31 \% \& 39.80 \%)$ and 91 to 180 days ( $50.75 \% \& 43.88 \%$ ) respectively ( Table $1 \& 2$ ). These findings are in conformity with the earlier report of Samad (2001b) who reported low level of parasitic infection in calves up to 30 days of age in comparison to higher age group. It indicates that the rate of infection of enteropathogens increased with the increase of age of calves which is probably proportionate to the period of exposure to infection and incubation period of the disease.

Table 1. Pattern of occurrence of single and mixed gastro-intestinal parasites in diarrboeic calves

\begin{tabular}{|c|c|c|c|c|c|c|}
\hline \multirow[t]{2}{*}{$\mathrm{S} / \mathrm{N}$} & \multirow[t]{2}{*}{ Parasites } & \multicolumn{3}{|l|}{ Age in days } & \multicolumn{2}{|c|}{ Total $(n=100)$} \\
\hline & & $\begin{array}{l}10-30 \\
(n=16)\end{array}$ & $\begin{array}{l}31-90 \\
(n=37)\end{array}$ & $\begin{array}{l}91-180 \\
(n=47)\end{array}$ & No. & $\%$ \\
\hline 1. & Toxocara vitulorum ( TV ) & - & 03 & 01 & 04 & \\
\hline 2. & Gl nematodes (GIN) & 02 & 04 & 26 & 32 & \\
\hline 3. & Strongyloides sp. ( S ) & - & 01 & - & 01 & \\
\hline \multirow[t]{2}{*}{4.} & Eimeria sp. (E) & 02 & 03 & 02 & 07 & \\
\hline & Total (Single infection ) & 04 & 11 & 29 & 44 & $65.67 *$ \\
\hline 5. & $\mathrm{GIN}+\mathrm{E}$ & 03 & 05 & 02 & 10 & \\
\hline 6. & $\mathrm{TV}+\mathrm{E}$ & 01 & 06 & - & 07 & \\
\hline 7. & GIN + Moniezia sp. ( M) & - & - & 01 & 01 & \\
\hline 8. & GIN + Paramphisiomum sp. & - & - & 01 & 01 & \\
\hline \multirow[t]{2}{*}{9.} & GIN + TV & - & 01 & - & 01 & \\
\hline & Total ( Concurrent - 2 types ) & 04 & 12 & 04 & 20 & 29.85 \\
\hline 10. & $\mathrm{TV}+\mathrm{GIN}+\mathrm{E}$ & - & 02 & - & 02 & \\
\hline \multirow[t]{4}{*}{11.} & GIN + Trichuris sp. $+\mathrm{E}$ & - & - & 01 & 01 & \\
\hline & Total ( Concurrent - 3 types ) & - & 02 & 01 & $\mathbf{0 3}$ & 03.33 \\
\hline & Total (Concurrent infection) & 04 & 14 & 05 & 23 & 34.33 \\
\hline & Overall (single + mixed ) & $08(11.94 \%)$ & $25(37.31 \%)$ & $34(50.75 \%)$ & 67 & 67.00 \\
\hline
\end{tabular}

$n=$ No. of calves examined. *Significant at $(\mathrm{p}<0.01)$ 
Parasitic and bacterial enteropathogens

Table 2. Pattern of occurrence of bacterial enteropathogens in diarrhoeic calves

\begin{tabular}{|c|c|c|c|c|c|c|}
\hline \multirow[t]{2}{*}{$\mathrm{S} / \mathrm{N}$} & \multirow[t]{2}{*}{ Bacteria } & \multicolumn{3}{|l|}{ Age in days } & \multicolumn{2}{|c|}{ Total $(n=100)$} \\
\hline & & $\begin{array}{l}10-30 \\
(n=16)\end{array}$ & $\begin{array}{l}31-90 \\
(n=37)\end{array}$ & $\begin{array}{l}91-180 \\
(n=47)\end{array}$ & No. & $\%$ \\
\hline 1. & Escherichia coli ( $\mathrm{EC})$ & 01 & 04 & 03 & 08 & \\
\hline 2. & Bacillus sp. ( B ) & 09 & 18 & 24 & 51 & \\
\hline \multirow[t]{2}{*}{3.} & Staphylococcus sp.(Staph.) & - & 01 & - & 01 & \\
\hline & Total ( Single infection ) & 10 & 23 & 27 & 60 & 61.22 \\
\hline 4. & $\mathrm{~B}+\mathrm{EC}$ & 05 & 10 & 10 & 25 & \\
\hline 5. & B + Staph. & - & 03 & 01 & 04 & \\
\hline 6. & B + Salmonella sp. & - & 01 & 04 & 05 & \\
\hline \multirow[t]{2}{*}{7.} & $\mathrm{EC}+$ Staph. & 01 & 01 & 01 & 03 & \\
\hline & Total ( Concurrent - 2 types ) & 06 & 15 & 16. & 37 & 37.76 \\
\hline \multirow[t]{5}{*}{8.} & $\mathrm{EC}+\mathrm{B}+\mathrm{Staph}$ & $\cdot$ & 01 & - & 01 & 01.02 \\
\hline & Total ( Concurrent infection ) & 06 & 16 & 16 & 38 & 38.78 \\
\hline & Total + ve & $16(16.33)$ & $39(39.80)$ & $43(43.88)$ & 98 & 98.00 \\
\hline & Total - ve & $01(50.00)$ & - & $01(50.00)$ & 02 & 02.00 \\
\hline & Overall & 17 & 39 & 44 & 100 & 100 \\
\hline
\end{tabular}

$\mathrm{n}=$ No. of calves examined.

Analysis of the results of concurrent infection with GI parasites and bacteria showed that only $18.18 \%$ calves had single bacterial infection, $42.42 \%$ had two types, $30.30 \%$ three types, $8.08 \%$ four types and only $1.01 \%$ five types of infections of either with bacteria or parasites or both ( Table 3 ). 1t appears from the summary of the Table 3 that $18.14 \%$ diarrhoeic calves were affected with single types of bacteria, $14 \%$ with mixed bacteria, only $1 \%$ with concurrent two types of parasites but $66 \%$ calves had concurrent infection with multiple bacteria and parasites ( Table 3 ). Although single bacterial enteropathogen could be associated with diarrhoea in calves ( $18.18 \%$ ) but significantly higher rate of dirrhoeic calves ( $81.82 \%$ ) were associated with concurrent infection either with multiple bacteria or parasites or both ( Table 3 ). It may be concluded from the results of this study that GI parasites may not be responsible alone for the production of clinical diarrhoea in calves.

\section{Gastro-intestinal parasitic infections}

Microscopic examination of faecal samples of 100 diarrhoeic calves aged between 10 to 180 days showed higher rate of infection with GN nematodes ( $48.0 \%$ ), followed by Eimeria sp. ( $27.0 \%$ ), Toxocara vitulorum ( $14.0 \%)$ and lowest of $1 \%$ with each of the Strongyloides sp., Paramphistomum sp., and Moniezia sp. ( Table 4 ).

The species of the GI nematode parasites associated with diarrhoea in calves have not been identified in this study and presence of any nematode eggs other than Toxocara, Strongyloides and Trichuris infection were considered to be GI nematodes. The $48 \%$ clinical occurrence of GIN recorded in calves up to 180 days of age supports the earlier report of Samad (2001b) who reported $32.73 \%$ prevalence of parasitic gastro-enteritis caused by nematode parasites in calves. It appears that the clinical GI nematode infection started at the age of 30 days ( $10.42 \%)$ and then a steady increased with the age and highest rate was found at"91 to 180 days $(64.58 \%$ ) of age ( Table 4 ).

Reports on the incidence of clinical bovine coccidiosis are very scanty in Bangladesh. However, Mondal and Qadir (1978) and Karim et al. (1990) reported subclinical infection of coccidiosis with identification of species of causative Eimeria. Six species of Eimeria identified in cattle of Bangladesh were : E. zurnii, E. bovis, E. auburnensis, E. cylindrica, E. subspherica and E. bukidnonensis. In this study, clinical coccidiosis was recorded in $27 \%$ calves aged between 25 to 180 days but higher infection rate ( $59.26 \%$ ) was observed in calves aged between 31 to 90 days ( Table 4 ). These findings support the report of Radostits et al. (2000) who reported 15 to 20 days prepatent and 6 to 30 days incubation period of Eimeria infection.

Although the $T$. vitulorum infection was recorded at the 15 th days of age but higher infection rate was recorded in calves aged between 31 to 90 days ( $85.71 \%$ ) of age in comparison to 10 to $30(7.14 \%)$ and 90 to $180(7.14 \%)$ days ( Table 4 ). This finding supports the earlier report of Karim et al. (1998) who reported $44 \%$ subclinical $T$. vitulorum 
Table 3. Pattern of occurrence of parasitic and bacterial enteropathogens in diarrhoeic calves

\begin{tabular}{|c|c|c|c|c|c|c|}
\hline \multirow[t]{2}{*}{$\mathrm{S} / \mathrm{N}$} & \multirow[t]{2}{*}{ Parasites } & \multicolumn{3}{|c|}{ Age ( days) } & \multicolumn{2}{|c|}{ Total $(\mathbf{n}=100)^{*}$} \\
\hline & & $\begin{array}{l}10-30 \\
(n=16)\end{array}$ & $\begin{array}{l}31-90 \\
(n=37)\end{array}$ & $\begin{array}{l}91-180 \\
(n=47)\end{array}$ & No. & $\%$ \\
\hline 1. & Bacillus sp. (B) & 02 & 06 & 07 & 15 & \\
\hline \multirow[t]{2}{*}{2.} & Escherichia coli ( EC) & 01 & - & 02 & 03 & \\
\hline & Total (Single infection) & 03 & 06 & 09 & 18 & 18.18 \\
\hline 3. & $B+E C$ & 04 & 05 & 01 & 10 & \\
\hline 4. & B + Staphylococcus sp. ( Staph.) & - & 01 & - & 01 & \\
\hline 5. & $\mathrm{~B}+$ Eimeria sp. ( E) & 02 & 02 & 02 & 06 & \\
\hline 6. & B + GI nematodes ( GIN) & 02 & 04 & 13 & 19 & \\
\hline 7. & EC + Staph. & - & 01 & 01 & 02 & \\
\hline 8. & EC + Toxocara vitulorum ( TV ) & - & 01 & - & 01 & \\
\hline 9. & $\mathrm{EC}+\mathrm{GIN}$ & - & 0 I & 01 & 02 & \\
\hline \multirow[t]{2}{*}{10.} & GIN + Paramphistomun sp. & - & - & 01 & 01 & \\
\hline & Total (Concurrent - 2 types) & 08 & 15 & 19 & 42 & 42.42 \\
\hline 11. & $\mathrm{~B}+\mathrm{S}+\mathrm{GIN}$ & - & - & 03 & 03 & \\
\hline 12. & $B+$ Staph. $+E C$ & - & 01 & - & 01 & \\
\hline 13 & B + Staph. + GIN & - & - & 01 & 01 & \\
\hline 14. & $B+E C+G I N$ & - & 01 & 06 & 07 & \\
\hline 15. & $B+E C+T V$ & - & 02 & 01 & 03 & \\
\hline 16. & $B+T V+E$ & 01 & 01 & - & 02 & \\
\hline 17. & B + Moniezia sp. + GIN & - & - & 01 & 01 & \\
\hline 18. & $\mathrm{~B}+\mathrm{E}+\mathrm{GIN}$ & 03 & 03 & 01 & 07 & \\
\hline 19. & Staph + EC + GIN & - & 01 & 01 & 02 & \\
\hline 20. & Staph. + EC + E & - & 01 & - & 01 & \\
\hline 21. & Staph. + GIN + E & - & 01 & - & 01 & \\
\hline \multirow[t]{2}{*}{22.} & $E C+T V+E$ & - & 01 & - & 01 & \\
\hline & Total (Concurrent -3 types ) & 04 & 12 & 14 & 30 & $\mathbf{3 0 . 3 0}$ \\
\hline 23. & $B+E C+G I N+E$ & - & 01 & 01 & 02 & \\
\hline 24. & $\mathrm{~B}+$ Staph + GIN $+E$ & - & 01 & - & 01 & \\
\hline 25. & $B+E C+T V+E$ & 01 & 02 & - & 03 & \\
\hline 26. & $B+S+T V+E$ & - & 01 & - & 01 & \\
\hline \multirow[t]{2}{*}{27.} & $\mathrm{~B}+\mathrm{E}+\mathrm{GIN}+\mathrm{TV}$ & - & 01 & - & 01 & \\
\hline & Total (Concurrent -4 types) & 01 & 06 & 01 & 08 & 08.08 \\
\hline \multirow[t]{3}{*}{28.} & $\mathrm{~B}+\mathrm{EC}+\mathrm{GIN}+$ Trichuris $\mathrm{sp}+\mathrm{E}$ & - & - & 01 & 01 & \\
\hline & Total (Concurrent -5 types) & - & - & 01 & $0 \mathrm{I}$ & 01.01 \\
\hline & Total ( Concurrent infection) & 13 & 33 & 35 & 81 & 81.82 \\
\hline & otal +ve ( single + mixed $)$ & $16(16.33)$ & $39(39.79)$ & $44(43.88)$ & 99 & 99.00 \\
\hline
\end{tabular}

*One calf (14-day-old) was negative for both parasite and bacteria, 18 calves had single bacteria, 14 had concurrent bacteria, one had concurrent parasites and 66 had concurrent bacteria and parasitic infections.

infection rate in calves aged between 1 to 3 months ( $60 \%$ ) than 4 to 6 months ( $28 \%$ ) old calves. The findings of occurrence of clinical $T$. vitulorum infection in neonatal calves within the 1 st two weeks of life suggest that the T. vitulorum larvae have been passed to newborn calves through colostrum / milk ( Mia et al., 1975). This result also supports the description of Radostits et al. (2000) who reported that $T$. vitulorum larvae are passed in great numbers in the colostrum 2 to 5 days after calving, worms are matured in the intestine of the calves by 10 days of age and eggs are passed by 3 weeks and then the adult worms are expelled from the intestine by 5 month of age, and for this reason, toxocariasis has been considered as calfhood disease.

Only one case of Strongyloides papillosus infection in calf was recorded at the age of 45 days ( Table 4 ). This finding supports the earlier observations of Moyo et al. (1996) and Bharkad et al. (1999) who reported $S$. papillosus infection in calves of 2 to 4 months and up to 3 months of age, respectively. 
Parasitic and bacterial enteropathogens

Table 4. Age-wise occurrence of parasitic and bacterial enteropathogens associated with diarrhoea in calves

\begin{tabular}{|c|c|c|c|c|c|c|}
\hline \multirow[t]{2}{*}{$\mathrm{S} / \mathrm{N}$} & \multirow[t]{2}{*}{ Enteropathogens } & \multicolumn{3}{|l|}{ Age in days } & \multicolumn{2}{|c|}{ Total $(n=100)$} \\
\hline & & $\begin{array}{l}10-30 \\
(n=16)\end{array}$ & $\begin{array}{l}31-90 \\
(n=37)\end{array}$ & $\begin{array}{l}91-180 \\
(n=47)\end{array}$ & No. & $\%$ \\
\hline$\overline{\mathbf{A} .}$ & Parasites & & & & & \\
\hline 1. & Toxocara vitulorum & $01^{a}(07.14)$ & $12(85.71)$ & $01(07.14)$ & 14 & 14.00 \\
\hline 2. & GI nematodes & $05^{b}(10.42)$ & $12(25.00)$ & $31(64.58)$ & 48 & 48.00 \\
\hline 3. & Strongyloides sp. & - & $01^{c}(100)$ & - & 01 & 01.00 \\
\hline 4. & Paramphistomum sp. & - & - & $01^{d}(100)$ & 01 & 01.00 \\
\hline 5. & Moniezia sp. & - & - & $01^{e}(100)$ & 01 & 01.00 \\
\hline $\begin{array}{l}6 . \\
\text { B. }\end{array}$ & $\begin{array}{l}\text { Eimeria sp. } \\
\text { Bacteria }\end{array}$ & $06^{f}(22.22)$ & $16(59.26)$ & $05(18.52)$ & 27 & 27.00 \\
\hline 1. & Staphylococcus sp. & $01^{x}(11.11)$ & $06(66.67)$ & $02(22.22)$ & 09 & 09.00 \\
\hline 2. & Bacillus sp. & $13^{Y}(14.94)$ & $32(36.78)$ & $42(48.28)$ & 87 & 87.00 \\
\hline 3. & Escherichia coli & $07^{\curlyvee}(18.92)$ & $14(37.84)$ & $16(43.24)$ & 37 & 37.00 \\
\hline 4. & Salmonella sp. & - & $01^{z}(20.00)$ & $04 \quad(80.00)$ & 05 & 05.00 \\
\hline
\end{tabular}

$\mathrm{n}=$ No. of calves examined. $\mathrm{GI}=$ Gastro-intestinal. $\quad-=$ Negative

1 st recorded at the age of : " 15 days, ' 30 days, $\quad{ }^{\mathrm{c}} 45$ days, $\quad{ }^{\mathrm{d}} 150$ days, ${ }^{\mathrm{c}} 91$ days, $\quad 25$ days, $\quad{ }^{\mathrm{x}} 30$ days, ${ }^{\mathrm{y}} 10$ days, $\quad{ }^{\mathrm{x}} 60$ days

Paramphistomum infection was recorded in only one calf at the age of 150 days ( Table 4 ). The presence of adult paramphistomes in the rumen has said not to be elicited any clinical response but in massive infestations are associated with the clinical signs ( Radostits et al., 2000 ). However, this calf affected with adult Paramphistomum (epg 700 ) which resulted fetid diarrhoea and ill-health.

Moniezia infection was recorded in one calf at the age of 91 days ( Table 4 ). This finding supports the Radostits $e t$ al. (2000) who described the signs of Moniezia infestation are restricted chiefly to animals less than six month of age. The clinical manifestation of Moniezia infestation have been described to be associated with diarthoea and ill-health which are in conformity with the earlier report of Samad et al. (1977) who reported an outbreak of monieziasis with diarrhoea and ill-health in calves.

\section{Bacterial enteropathogens}

Bacteriological examination of 100 diarrhoeic faecal samples of calves showed that $98 \%$ calves had either single or concurrent infection with four different types of bacteria ( Table 2 ). Higher infection rate was recorded with Bacillus sp. ( $87 \%$ ), followed by E. coli ( $37 \%$ ), Staphylococcus sp. ( $9.0 \%$ ) and lowest with Salmonella sp. ( $5 \%$ ) of organisms ( Table 4 ). The Bacillus sp. and E. coli organisms were recorded in the faeces from the 10 days age of calves, and Staphylococcus sp. from 30 days of age but Salmonella sp. from 60 days of age in diarrhoeic calves ( Table 4 ). These rates of infection support the earlier reports of Debnath et al. (1987) who reported $20 \%$ E. coli and $3 \%$ Salmonella infection in diarrhoeic calves. Amin et al. (1988) also reported the prevalence of enteropathogenic $E$. coli in $10 \%, 8.57 \%$ and $9.38 \%$ diarrhoeic calves under one year of age in three different dairy farms in Bangladesh.

\section{REFERENCES}

1. Amin MM, Rahman MH, Ali MR, Huq $\mathrm{Hl}$ and Choudhury KA (1988). Diarrhoea due to Escherichia coli in calves. Bangladesh Veterinary Joumal $22: 7-12$.

2. Bharkad GP, Deshpande PD and Narladkar BW (1999). Gastro-intestinal parasitosis in bovine calves in Marathwada. Journal of Veterinary Parasitology 13:143-146.

3. Cheesbrough M (1985). Culturing of Anaerobes. In : Medical Laboratory Manual for Tropical Countries. 2nd edn., Butterworth Co., Kent, UK.

4. Cowan ST (1985). Cowan and Steel's Manual for Identification of Medical Bacteria. 2nd edn., Cambridge University Press, London.

5. Debnath NC, Huq Ml and Rahman A (1987). A microbial investigation of neonatal calf diarrhoea in Bangladesh. Indian Journal of Animal Science $57: 1035-1038$.

6. Debnath NC, Sill BK, Selim SA, Pradhan MAM and Howliader MMR (1990). A retrospective study of calf mortality and morbidity on smallholder traditional farms in Bangladesh. Preventive Veterinary Medicine $9: 1-7$.

7. Gupta SP (1982). Statistical Methods. 16th edn., Sultan Chand \& Son, New Delhi. 
8. Hossain MI, Hossain MM, Hannen BMA and Wadud A (1992). A note on mortality in young calves due to gastro-intestinal helminthiasis in and around BAU campus. Bangladesh Joumal of Animal. Science $21: 127-129$.

9. Kanim MJ, Begum N and Rahman MH (1990). Age susceptibility and seasonal dynamics of coccidiosis in cattle and sheep. Bangladesh Veterinarian $7: 22-26$.

10. Karm R, Rafiq K, Mostofa M and Hasan Q (1998). Therapeutic trials of certain anthelmintics against ascariasis in calves. Bangladesh Veterinary Journal $32: 71-73$,

11. Mia SA, Dewan ML, Uddin M and Chowdhury MUA (1975). The route of infection of buffalo calves by Toxocara (Neouscaris) vitulorum. Tropical Animal Health.and Production 7:153 - 156.

12. Mondal MMH and Qadir ANMA (1978). A preliminary investigation on the incidence of coccidial infestation in fowls, sheep, goats and cattle. Bangladesh Veterinary Journal $12: 7-11$.

13. Moyo DZ, Bwangamoi O, Hendrikx WML and Eysker M (1996). The epidemiology of gastro-intestinal nematode infections in communal cattle and commercial beef cattle on the Highveld of Zimbabwe. Veterinary Parasitology $67: 105-120$.

14. Radostits OM, Gay CC, Blood DC and Hinchcliff KM (2000). Veterinary Medicine. 9th edn., W. B. Saunders, London.

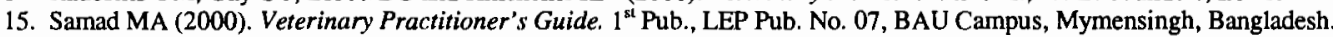

16. Samad MA (2001 a). Poshu Palon O Chikitsavidya. 2nd edn., LEP Pub. No. 08, BAU Campus, Mymensingh, Bangladesh.

17. Samad MA (2001b). Epidemiological studies on gastro-intestinal parasitosis in calves under traditional management in Bangladesh. Bangladesh Veterinary Joumal $35: 9-18$.

18. Samad MA, Haque AKMF, Rahman A, Ali KM and Sen MM (1977). Clinico-pathological report of an acute outbreak of monieziasis in calves. Bangladesh Veterinary Journal $11: 81-84$. 